\title{
Studi Eksperimental Kuat Tumpu Baut Sejajar Serat Metode Lubang Penuh dan Setengah Lubang
}

\author{
ERMA DESMALIANA, NESSA VALIANTINE DIREDJA, OKI BERNADI
}

\author{
Program Studi Teknik Sipil, Institut Teknologi Nasional Bandung \\ Email: ermadesmaliana@itenas.ac.id
}

\begin{abstract}
ABSTRAK
Kuat tumpu baut merupakan salah satu parameter penting dalam menentukan suatu sambungan baut. Berdasarkan persamaan SNI 7973:2013, kuat tumpu ditentukan berdasarkan berat jenis kayu, diameter pengencang, dan arah serat kayu. Pada penelitian kali ini terdapat dua metode pengujian eksperimental yaitu metode lubang penuh dan metode setengah lubang berdasarkan ASTM D5764-97a (2002). Pengujian dilakukan menggunakan kayu Mahoni dengan sejajar arah serat dan tiga variasi diameter baut yaitu $1 / 2$ inchi, 5/8 inchi dan 3/4 inchi yang dibandingkan dengan analisis teoritis berdasarkan SNI 7973:2013. Hasil penelitian menunjukan bahwa pengujian eksperimental kuat tumpu baut memiliki nilai yang lebih besar dibandingkan dengan persamaan berdasarkan SNI 7973:2013, dengan nilai persen beda untuk pengujian metode lubang penuh sebesar 22,914\% untuk sampel a; 5,806\% untuk sampel b; 3,759\% untuk sampel $c$; sedangkan untuk pengujian menggunakan metode setengah lubang sebesar 20,927\% untuk sampel $A A ; 16,954 \%$ untuk sampel BB; $15,326 \%$ untuk sampel $C C$.
\end{abstract}

Kata kunci: kuat tumpu baut, sejajar serat, SNI 7973:2013

\begin{abstract}
Bolt bearing strength is one of the important parameters in bolt connetion design. According to the SNI 7973:2013, bearing strength is determined based on specific gravity of timber, diameter of fasterner and direction of timber grain. In this research, there are two experimental testing methods, full hole and half hole testing based on ASTM D5764-97a (2002). Mahogany timber with parallel grain direction was carried out in this test using three variations of bolt diameter, which are 1/2 in, 5/8 in and 3/4 in. This study compares the value of bolt bearing strength with theoritical analysis based on SNI 7973:2013. The result showed that the experimental of bearing strength had a greater value than the equation of theoritical analysis based on SNI 7973:2013, with percentage of difference for full hole testing are $22.914 \%$ for sample a, $5.806 \%$ for sample $b, 3.759 \%$ for sample c, while the percentage of difference for half hole testing are $20,297 \%$ for sample $A A, 16.954 \%$ for sample $B B$, and $15.326 \%$ for sample $C C$.
\end{abstract}

Keywords: bolt bearing strength, parallel grain, SNI 7973:2013 


\section{PENDAHULUAN}

Indonesia merupakan negara yang memiliki kekayaan dalam bidang pertanian dan kehutanan, salah satunya yaitu kayu. Kayu banyak digemari oleh masyarakat Indonesia karena memliki ketahanan, estetika dan meminimalisir terhadap dampak lingkungan. Kayu biasa digunakan oleh masyarakat dalam konstruksi bangunan, dan dalam proses pemilihan jenis kayu tidak dapat diabaikan karena jenis kayu yang tidak baik akan menimbulkan masalah. Salah satu kekurangan kayu adalah sifatnya yang non-homogen, cacat kayu dan keterbatasan dalam ukuran yang dibutuhkan untuk keperluan struktur bangunan. Sehingga apabila dalam proses konstruksi bangunan menggunakan jenis kayu yang kurang baik, maka bangunan yang dihasilkan tidak akan kokoh seperti yang diharapkan.

Faktor-faktor yang mempengaruhi kekuatan kayu antara lain berat jenis, kadar air, lama pembebanan dan jenis kayu beserta lokasi cacat kayu. Berat jenis memiliki pengaruh besar terhadap kekuatan kayu. Pada umumnya semakin besar berat jenis kayu tersebut maka semakin besar pula kekuatan yang dihasilkan oleh kayu tersebut.

Di alam, kayu menjadi bahan yang terbatas dari segi ukuran yang diperlukan untuk memenuhi kebutuhan konstruksi, hal tersebut menyebabkan kayu perlu dilakukan penyambungan. Perencanaan sambungan kayu terdapat dalam SNI 7973:2013 dan harus memenuhi persyaratan yang ditentukan agar sambungan aman dan juga tidak mengalami kegagalan. Dalam proses penyambungan kayu, terdapat dua cara yaitu menggunakann perekat dan pasak (baut, sekrup kunci, sekrup kunci, paku/pantek, baut dorong, dan pin dorong). Perekat berguna untuk menambah kekuatan geser sejajar serat pada sambungan kayu sehingga lebih kuat dan efektif digunakan sebagai alternatif dalam penyambung kayu. Sedangkan dengan menggunakan pasak, kayu yang dihasilkan tidak mampu menahan beban yang cukup besar sehingga diperlukan pengujian untuk mengetahui seberapa efektif proses penyambungan dengan menggunakan pasak.

Pada setiap sambungan kayu perlu diperhatikan keutamaan dalam kekuatannya karena sering terjadinya beberapa jenis kegagalan salah satunya yaitu kegagalan tumpu baik pada komponen utama atau komponen samping dan kegagalan pada alat sambung. Oleh karena penelitian ini bertujuan untuk mengetahui perbedaan kuat tumpu baut hasil uji eksperimental metode lubang penuh dan metode setengah dengan dengan kuat tumpu berdasarkan SNI 7973:2013.

\section{TINJAUAN PUSTAKA}

Kuat tumpu pasak adalah kekuatan maksimum kayu pada sekeliling lubang yang dibebani pasak, parameter ini perlu diperhatikan karena akan mempengaruhi terhadap kekuatan sambungan kayu. Berdasarkan Badan Standardisasi Nasional (2013), besar kuat tumpu pasak kayu bergantung pada berat jenis kayu, serat miring dan yang paling berpengaruh yakni diameter pasak yang digunakan.

Berdasarkan ASTM D5764-97a (2002) mengenai pengujian kuat tumpu pasak yang didalamnya menyediakan prosedur dasar untuk mengevaluasi kuat tumpu pasak kayu maupun produk berbasis kayu lainnya, pengujian dilakukan dengan kecepatan $1 \mathrm{~mm} / \mathrm{menit}$. Hasil pengujian dilakukan untuk menentukan ketahanan beban dan deformasi karakteristik dari sambungan pada kayu maupun produk berbasis kayu yang dihasilkan dari penerapan beban yang disalurkan oleh alat pengencang yang dimasukkan kedalam lubang. Dalam melakukan pengujian kuat tumpu pasak terdapat 2 (dua) metode yaitu metode setengah lubang dan metode lubang penuh. 


\subsection{Metode Setengah Lubang}

Pada metode setengah lubang, benda uji, diberi setengah lubang di bagian atas dengan kedalaman setengah diameter baut. Pada saat pengujian baut diletakkan di bagian lubang dan ditekan hingga baut rata dengan permukaan benda uji. Konfigurasi benda uji-setengah lubang dapat dilihat pada Gambar 1.

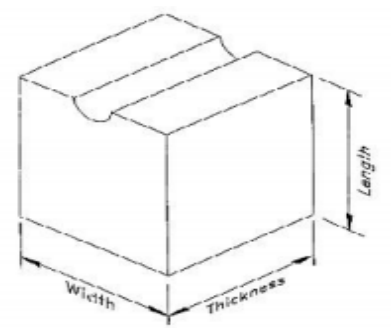

Gambar 1. Konfigurasi benda uji-setengah lubang

(Sumber: ASTM D 5764-97a, 2002)

$\begin{array}{lll}\text { dengan: } & \text { Tebal } & \geq \operatorname{minimum}(38 \mathrm{~mm} ; 2 \mathrm{D}) \\ & \text { Lebar } & \geq \operatorname{minimum}(50 \mathrm{~mm} ; 4 \mathrm{D}) \\ & \text { Panjang } & \geq \operatorname{minimum}(50 \mathrm{~mm} ; 4 \mathrm{D})\end{array}$

\subsection{Metode Lubang Penuh}

Metode lubang penuh bisa dipergunakan apabila benda uji cenderung untuk membelah sebelum pengujian selesai. Tes ini tepat untuk mempelajari efek dari beberapa faktor seperti diameter pasak, ukuran lubang pasak, kadar air dan serat miring. Namun, pada eksperimental disini hanya memakai sejajar serat kayu. Konfigurasi benda uji lubang penuh dapat dilihat pada Gambar 2.

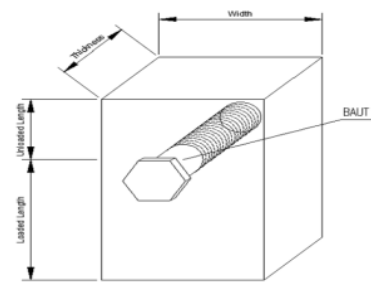

\section{Gambar 2. Konfigurasi benda uji-lubang penuh}

(Sumber: ASTM D 5764-97a, 2002)

$\begin{array}{lll}\text { dengan: } & \text { Tebal } & \geq \text { minimum }(38 \mathrm{~mm} ; 2 D) \\ & \text { Lebar } & \geq \text { maksimum }(50 \mathrm{~mm} ; 4 D) \\ & \text { Panjang terbebani } & \geq \text { maksimum }(50 \mathrm{~mm} ; 4 D) \\ & \text { Panjang tak terbebani } & \geq \text { maksimum }(25 \mathrm{~mm} ; 2 D)\end{array}$

Kuat tumpu pasak menurut ASTM D5764-97a (2002), dapat didefinisikan pada Persamaan 1 berikut:

$$
F_{e}=\frac{P_{5 \%}}{(D \times t)}
$$

dengan: $\quad F_{e} \quad=$ kuat tumpu pasak [MPa],

$P_{5 \%} \quad=$ beban pada saat $5 \%$ offset $[\mathrm{N}]$,

$D=$ diameter alat pengencang $[\mathrm{mm}]$,

$t=$ tebal benda uji [mm]. 
Kuat tumpu baut juga dapat dihitung menggunakan persamaan yang ada dalam SNI 7973:2013 yaitu:

Untuk diameter baut $\geq 6,35 \mathrm{~mm}$

$$
F_{e}=70 G \mathrm{MPa}
$$

Untuk diameter baut $<6,35 \mathrm{~mm}$

$$
F_{e}=100 G^{1,84} \mathrm{MPa}
$$

dengan: $\quad G=$ berat jenis kayu $\left[\mathrm{gr} / \mathrm{cm}^{3}\right]$.

Berdasarkan Persamaan 2 dan Persamaan 3, didapat nilai 70 dan 100 yang dikalikan dengan berat jenis. Nilai dari persamaan tersebut berasal dari penyempurnaan hasil pengujian eksperimental terdahulu yaitu oleh Wilkinson (1991). Wilkinson menurunkan persamaan empiris untuk kuat tumpu menggunakan beban sejajar dan tegak lurus serat kayu dengan Persamaan 4 dan Persamaan 5 berikut:

$$
\begin{aligned}
& F_{e \|}=77,25 G \mathrm{MPa} \\
& F_{e \perp}=42,1 G \mathrm{MPa}
\end{aligned}
$$

dengan: $\quad F_{e \|} \quad=$ kuat tumpu sejajar serat [MPa],

$F_{e \perp} \quad=$ kuat tumpu tegak lurus serat [MPa],

$P_{5 \%} \quad=$ beban pada saat $5 \%$ offset [N],

$G=$ spesific gravity berdasarkan berat-volume kering oven,

$D \quad=$ diameter baut $[\mathrm{mm}]$.

Karena studi yang dilakukan memiliki keterbatasan yaitu hanya untuk berat jenis 0,36 sampai dengan 0,52 dengan diameter baut 19,1 mm. Maka, Smith et al. (1988) melakukan pengujian juga untuk Eurocode 5 yang menemukan bahwa kuat tumpu baut dapat dipegaruhi oleh diameter baut. Pada akhirnya NDS-2005 mengeluarkan Persamaan 6, Persamaan 7 dan Persamaan $\mathbf{8}$ untuk menghitung kuat tumpu baut berikut:

$$
\begin{aligned}
& F_{e \|}=78,8 G \mathrm{MPa} \text { untuk } D \geq 6,35 \mathrm{~mm} \\
& F_{e \|}=117 G^{1,84} \mathrm{MPa} \text { untuk } D<6,35 \mathrm{~mm} \\
& F_{e \perp}=42,9 G^{1,45} D^{-0,5} \mathrm{MPa}
\end{aligned}
$$

\section{METODE PENELITIAN}

Tahapan kegiatan penelitian dapat dilihat lebih rinci pada Gambar 3. 


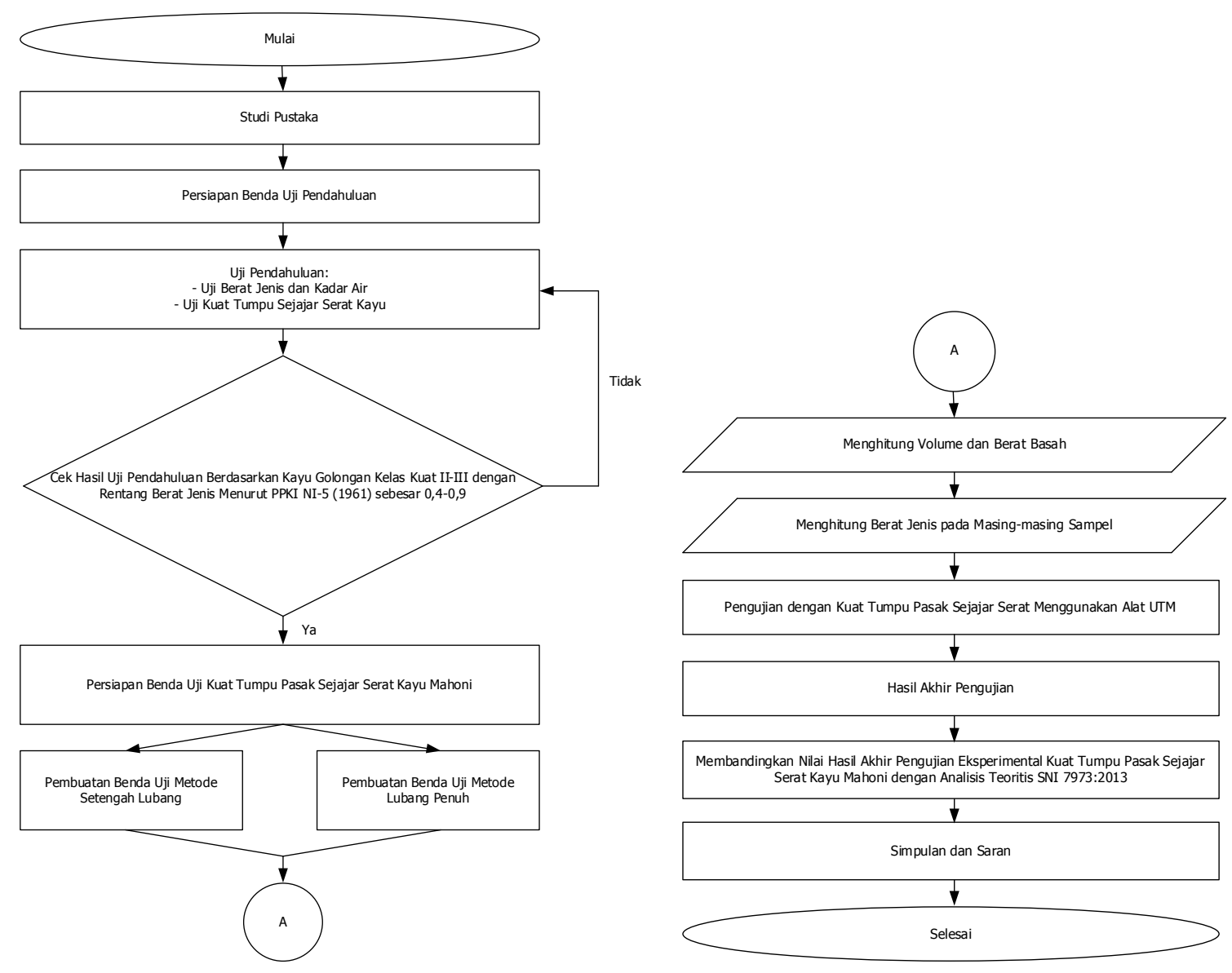

Gambar 3. Tahapan penelitian

Metode yang dilakukan pada penelitian ini dengan dua metode, yaitu dengan cara analisis dan berdasarkan hasil pengujian eksperimental. Pada metode analisis teoritis berdasarkan SNI 7973:2013, sedangkan pada pengujian eksperimental mengacu pada ASTM D5764-97a (2002). Dalam pengujian kuat tumpu pasak, terdapat dua metode yang digunakan yaitu metode setengah lubang dan metode lubang penuh.

Nilai kuat tumpu baut secara eksperimental sesuai dengan ASTM D5764-97a (2002), dapat dicari setelah mendapatkan $P_{5 \%}$ dari hasil offset pada grafik lalu memasukan nilai tersebut ke dalam Persamaan 1. Sedangkan secara teoritis nilai kuat tumpu baut dapat dicari dengan menggunakan Persamaan 2 dan Persamaan 3.

\section{HASIL DAN PEMBAHASAN}

\subsection{Uji Kuat Tumpu Pasak Sejajar Serat Kayu}

Pengujian kuat tumpu baut sejajar serat kayu dilakukan di laboratorium Metalurgi Fisik Institut Teknologi Nasional Bandung dengan menggunakan metode setengah lubang dan metode lubang penuh seperti pada Gambar 4 (a) dan Gambar 4 (b). 


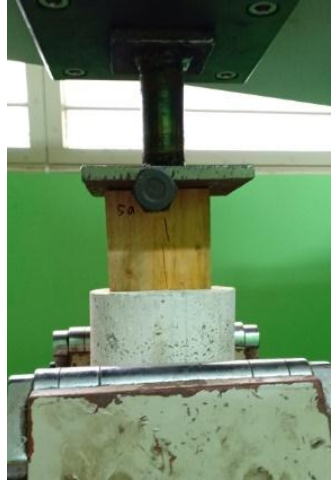

(a)

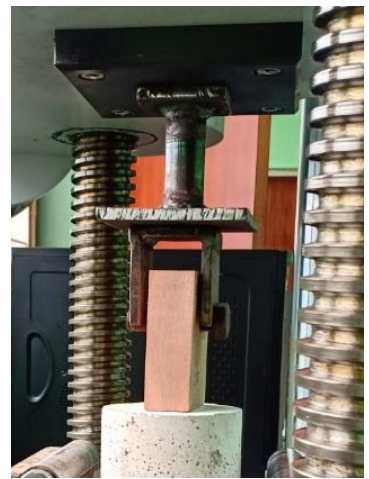

(b)

Gambar 4. Pengujian kuat tumpu baut dengan metode setengah lubang (a) dan metode lubang penuh (b)

Hasil output di komputer dari uji kuat tumpu di laboratorium dengan menggunakan alat UTM berupa grafik garis berwarna biru dengan telah dilakukan penarikan garis $\boldsymbol{P}_{\mathbf{5} \%}$ yang berwarna merah secara manual untuk mendapatkan beban offset $5 \%$ dari diameter baut.

\subsubsection{Metode Lubang Penuh (Full Hole)}

Pada pengujian ini, metode lubang penuh ( Full Hole) digunakan untuk kayu yang memiliki sifat yang lebih keras. Berikut adalah data-data yang dihasilkan dari pengujian kuat tumpu baut sejajar serat kayu Mahoni dengan menggunakan metode lubang penuh:

Tabel 1. Berat Jenis Menggunakan Metode Lubang Penuh

\begin{tabular}{|c|c|c|c|c|c|c|c|c|}
\hline Sampel & $\begin{array}{c}\text { No. } \\
\text { Sampel }\end{array}$ & $\begin{array}{c}\text { Volume } \\
\text { Lubang } \\
{\left[\mathrm{cm}^{3}\right]}\end{array}$ & $\begin{array}{c}\text { Berat } \\
\text { [gr] }\end{array}$ & $\begin{array}{l}\text { Lebar } \\
{[\mathrm{cm}]}\end{array}$ & $\begin{array}{l}\text { Tebal } \\
{[\mathrm{cm}]}\end{array}$ & $\begin{array}{c}\text { Tinggi } \\
{[\mathrm{cm}]}\end{array}$ & $\begin{array}{c}\text { Volume } \\
\text { Sampel } \\
\text { [cm3] }\end{array}$ & $\begin{array}{c}\text { Berat Jenis } \\
{\left[\mathrm{gr} / \mathrm{cm}^{3}\right]}\end{array}$ \\
\hline \multirow{5}{*}{ a } & 1 & 3,44 & 64 & 5,20 & 2,72 & 7,70 & 105,46 & 0,61 \\
\hline & 2 & 3,46 & 65 & 5,23 & 2,73 & 7,76 & 107,23 & 0,61 \\
\hline & 3 & 3,41 & 65 & 5,19 & 2,70 & 7,89 & 106,95 & 0,61 \\
\hline & 4 & 3,42 & 64 & 5,30 & 2,70 & 7,70 & 106,77 & 0,60 \\
\hline & 5 & 3,39 & 66 & 5,30 & 2,68 & 7,73 & 106,40 & 0,62 \\
\hline \multirow{5}{*}{ b } & 1 & 6,39 & 121 & 6,63 & 3,23 & 9,51 & 197,27 & 0,61 \\
\hline & 2 & 6,29 & 124 & 6,64 & 3,18 & 9,64 & 197,26 & 0,63 \\
\hline & 3 & 6,28 & 122 & 6,68 & 3,18 & 9,60 & 197,33 & 0,62 \\
\hline & 4 & 6,31 & 123 & 6,14 & 3,19 & 9,68 & 183,29 & 0,67 \\
\hline & 5 & 7,27 & 122 & 6,63 & 3,68 & 9,54 & 225,17 & 0,54 \\
\hline \multirow{5}{*}{ c } & 1 & 11,14 & 232 & 8,00 & 3,91 & 12,03 & 365,00 & 0,64 \\
\hline & 2 & 11,40 & 238 & 8,00 & 4,00 & 11,99 & 372,12 & 0,64 \\
\hline & 3 & 11,34 & 234 & 8,01 & 3,98 & 11,90 & 368,03 & 0,64 \\
\hline & 4 & 11,22 & 229 & 8,04 & 3,94 & 12,06 & 370,65 & 0,62 \\
\hline & 5 & 11,17 & 231 & 8,00 & 3,92 & 12,00 & 365,15 & 0,63 \\
\hline
\end{tabular}

Seperti pada Persamaan 4, hasil berat jenis dipengaruhi oleh masing-masing dimensi sampel, berat sampel, dan volume sampel. Pada Tabel 1, hasil berat jenis menunjukan bahwa ratarata dari tiap sampel kayu Mahoni telah sesuai dengan spesifikasi sifat mekanisnya (golongan kayu dengan kelas kuat II-III). 
Tabel 2. Kuat Tumpu Baut Sejajar Serat Berdasarkan Hasil Uji Eksperimental Menggunakan Metode Lubang Penuh

\begin{tabular}{|c|c|c|c|c|c|c|}
\hline Sampel & $\begin{array}{c}\text { No. } \\
\text { Sampel }\end{array}$ & $\begin{array}{c}\varnothing \text { baut } \\
{[\mathrm{mm}]}\end{array}$ & $\begin{array}{c}G \\
{\left[\mathrm{gr} / \mathrm{cm}^{3}\right]}\end{array}$ & $\begin{array}{l}P_{5 \%} \\
{[\mathbf{N}]}\end{array}$ & $\begin{array}{c}F_{\text {e eksperimen }} \\
\text { [MPa] }\end{array}$ & $\begin{array}{c}F_{\text {erata-rata }} \\
{[\mathrm{MPa}]}\end{array}$ \\
\hline \multirow{5}{*}{$\mathbf{a}$} & 1 & 12,7 & 0,61 & 19750 & 57,17 & \multirow{5}{*}{55,22} \\
\hline & 2 & 12,7 & 0,61 & 19100 & 55,09 & \\
\hline & 3 & 12,7 & 0,61 & 18108,93 & 52,91 & \\
\hline & 4 & 12,7 & 0,60 & 19500 & 56,87 & \\
\hline & 5 & 12,7 & 0,62 & 18400 & 54,06 & \\
\hline \multirow{5}{*}{ b } & 1 & 15,88 & 0,61 & 25330 & 49,4 & \multirow{5}{*}{45,68} \\
\hline & 2 & 15,88 & 0,63 & 23450 & 45,04 & \\
\hline & 3 & 15,88 & 0,62 & 23850 & 45,87 & \\
\hline & 4 & 15,88 & 0,67 & 24200 & 46,34 & \\
\hline & 5 & 15,88 & 0,54 & 24350 & 41,74 & \\
\hline \multirow{5}{*}{ C } & 1 & 19,05 & 0,64 & 32300 & 43,36 & \multirow{5}{*}{45,99} \\
\hline & 2 & 19,05 & 0,64 & 36850 & 48,36 & \\
\hline & 3 & 19,05 & 0,64 & 37250 & 49,13 & \\
\hline & 4 & 19,05 & 0,62 & 33500 & 44,63 & \\
\hline & 5 & 19,05 & 0,63 & 33200 & 44,46 & \\
\hline
\end{tabular}

Berdasarkan Tabel 2, hasil rata-rata yang didapatkan dari pengujian eksperimental kuat tumpu baut menggunakan metode lubang penuh pada sampel a sebesar 55,22 $\mathrm{MPa}$; sampel b sebesar 45,68 MPa; dan sampel c sebesar 45,99MPa.

Tabel 3. Kuat Tumpu Baut Sejajar Serat Berdasarkan Hasil Analisis Teoritis Menggunakan Metode Lubang Penuh

\begin{tabular}{|c|c|c|c|c|}
\hline Sampel & $\begin{array}{c}\text { No. } \\
\text { Sampel }\end{array}$ & $\begin{array}{c}\emptyset \text { baut } \\
{[\mathrm{mm}]}\end{array}$ & $\begin{array}{c}F_{e}=70 G \\
{[\mathrm{MPa}]}\end{array}$ & $\begin{array}{c}F_{\text {erata-rata }} \\
{[\mathrm{MPa}]}\end{array}$ \\
\hline \multirow{5}{*}{ a } & 1 & 12,7 & 42,48 & \multirow{5}{*}{42,57} \\
\hline & 2 & 12,7 & 42,43 & \\
\hline & 3 & 12,7 & 42,55 & \\
\hline & 4 & 12,7 & 41,96 & \\
\hline & 5 & 12,7 & 43,42 & \\
\hline \multirow{5}{*}{ b } & 1 & 15,875 & 42,94 & \multirow{5}{*}{43,02} \\
\hline & 2 & 15,875 & 44 & \\
\hline & 3 & 15,875 & 43,28 & \\
\hline & 4 & 15,875 & 46,98 & \\
\hline & 5 & 15,875 & 37,93 & \\
\hline \multirow{5}{*}{ c } & 1 & 19,05 & 44,49 & \multirow{5}{*}{44,26} \\
\hline & 2 & 19,05 & 44,77 & \\
\hline & 3 & 19,05 & 44,51 & \\
\hline & 4 & 19,05 & 43,25 & \\
\hline & 5 & 19,05 & 44,28 & \\
\hline
\end{tabular}

Berdasarkan Tabel 3, hasil rata-rata yang didapatkan dari Persamaan 2 untuk analisis teoritis pada sampel a sebesar 42,57 MPa; sampel b sebesar 43,02 $\mathrm{MPa}$; dan sampel c sebesar 44,26 MPa. 
Tabel 4. Perbandingan Hasil Uji Eksperimental Metode Lubang Penuh dengan Analisis Teoritis (SNI 7973:2013)

\begin{tabular}{ccccc} 
Sampel & $\begin{array}{c}\emptyset \text { baut } \\
{[\mathbf{m m}]}\end{array}$ & $\begin{array}{c}\boldsymbol{F}_{\text {erata-rata }} \\
\text { Eksperimen } \\
{[\mathrm{MPa}]}\end{array}$ & $\begin{array}{c}\boldsymbol{F}_{\text {erata-rata }} \\
\text { Analisis } \\
{[\mathrm{MPa}]}\end{array}$ & $\begin{array}{c}\text { Persen Beda } \\
{[\%]}\end{array}$ \\
\hline a & 12,7 & 55,22 & 42,57 & 22,91 \\
\hline b & 15,875 & 45,68 & 43,02 & 5,81 \\
\hline C & 19,05 & 45,99 & 44,26 & 3,76 \\
\hline
\end{tabular}

Hasil pengujian eksperimental kuat tumpu baut dengan metode lubang penuh menghasilkan nilai rata-rata lebih besar dari analisis teoritis seperti pada Gambar 4.4. Perbandingan dari persentase beda antara kuat tumpu eksperimental metode setengah lubang dengan analisis teoritis menunjukkan bahwa pada sampel a sebesar 22,91\%; sampel b sebesar 5,81\%; dan pada sampel c sebesar 3,76\%.

\subsubsection{Metode Setengah Lubang (Half Hole)}

Metode Setengah Lubang digunakan untuk kayu yang memiliki sifat yang lebih lunak. Berikut adalah data-data yang dihasilkan dari pengujian kuat tumpu baut sejajar serat kayu Mahoni dengan menggunakan metode metode setengah lubang:

Tabel 5. Berat Jenis Menggunakan Metode Setengah Lubang

\begin{tabular}{|c|c|c|c|c|c|c|c|c|}
\hline Sample & $\begin{array}{c}\text { No. } \\
\text { Sample }\end{array}$ & $\begin{array}{c}\text { Volume } \\
\text { Lubang } \\
{\left[\mathrm{cm}^{3}\right]}\end{array}$ & $\begin{array}{c}\text { Berat } \\
\text { [gr] }\end{array}$ & $\begin{array}{l}\text { Lebar } \\
{[\mathrm{cm}]}\end{array}$ & $\begin{array}{l}\text { Tebal } \\
{[\mathrm{cm}]}\end{array}$ & $\begin{array}{c}\text { Tinggi } \\
{[\mathrm{cm}]}\end{array}$ & $\begin{array}{c}\text { Volume } \\
\text { Sampel } \\
{\left[\mathrm{cm}^{3}\right]}\end{array}$ & $\begin{array}{c}\text { Berat Jenis } \\
{\left[\mathrm{gr} / \mathrm{cm}^{3}\right]}\end{array}$ \\
\hline \multirow{5}{*}{ AA } & 1 & 1,69 & 40 & 5,17 & 2,67 & 5,07 & 68,16 & 0,59 \\
\hline & 2 & 1,68 & 42 & 5,21 & 2,66 & 5,14 & 69,48 & 0,60 \\
\hline & 3 & 1,69 & 42 & 5,21 & 2,67 & 4,97 & 67,38 & 0,62 \\
\hline & 4 & 1,68 & 41 & 5,14 & 2,66 & 5,17 & 69,00 & 0,59 \\
\hline & 5 & 1,70 & 40 & 5,22 & 2,69 & 5,20 & 71,11 & 0,56 \\
\hline \multirow{5}{*}{ BB } & 1 & 3,21 & 74 & 6,51 & 3,25 & 6,42 & 132,62 & 0,56 \\
\hline & 2 & 3,17 & 73 & 6,51 & 3,20 & 6,22 & 126,41 & 0,58 \\
\hline & 3 & 3,21 & 72 & 6,44 & 3,25 & 6,39 & 130,33 & 0,55 \\
\hline & 4 & 3,19 & 74 & 6,54 & 3,23 & 6,32 & 130,31 & 0,57 \\
\hline & 5 & 3,20 & 72 & 6,44 & 3,24 & 6,28 & 127,83 & 0,56 \\
\hline \multirow{5}{*}{ CC } & 1 & 5,78 & 139 & 7,70 & 4,06 & 7,71 & 235,25 & 0,59 \\
\hline & 2 & 5,83 & 129 & 7,64 & 4,09 & 7,58 & 230,87 & 0,56 \\
\hline & 3 & 5,73 & 110 & 7,70 & 4,02 & 7,66 & 231,38 & 0,48 \\
\hline & 4 & 5,61 & 130 & 7,67 & 3,94 & 7,69 & 226,78 & 0,57 \\
\hline & 5 & 5,77 & 114 & 7,80 & 4,05 & 7,67 & 236,43 & 0,48 \\
\hline
\end{tabular}

Seperti pada Persamaan 4, hasil dari berat jenis dipengaruhi oleh masing-masing dimensi sampel, berat sampel, dan volume sampel. Pada Tabel $\mathbf{5}$ hasil berat jenis menunjukan bahwa rata-rata dari tiap sempel kayu Mahoni telah sesuai dengan spesifikasi sifat mekanisnya (golongan kayu dengan kelas kuat II-III). 
Tabel 6. Kuat Tumpu Baut Sejajar Serat Berdasarkan Hasil Uji Eksperimental menggunakan Metode Setengah Lubang

\begin{tabular}{|c|c|c|c|c|c|c|}
\hline Sampel & $\begin{array}{c}\text { No. } \\
\text { Sampel }\end{array}$ & $\begin{array}{l}\varnothing \text { baut } \\
{[\mathrm{mm}]}\end{array}$ & $\underset{\left[\mathrm{gr} / \mathrm{cm}^{3}\right]}{G}$ & $\begin{array}{l}P_{\mathbf{5} \%} \\
{[\mathbf{N}]}\end{array}$ & $\begin{array}{c}F_{\text {e eksperimen }} \\
\text { [MPa] }\end{array}$ & $\begin{array}{c}F_{\text {erata-rata }} \\
\text { [MPa] }\end{array}$ \\
\hline \multirow{5}{*}{$\mathbf{A A}$} & 1 & 12,7 & 0,59 & $20.100,00$ & 59,28 & \multirow{5}{*}{52,61} \\
\hline & 2 & 12,7 & 0,60 & $17.650,00$ & 52,25 & \\
\hline & 3 & 12,7 & 0,62 & $15.650,00$ & 46,15 & \\
\hline & 4 & 12,7 & 0,59 & $19.644,97$ & 58,15 & \\
\hline & 5 & 12,7 & 0,56 & $16.100,00$ & 47,21 & \\
\hline \multirow{5}{*}{ BB } & 1 & 15,88 & 0,56 & $24.400,00$ & 47,73 & \multirow{5}{*}{47,52} \\
\hline & 2 & 15,88 & 0,58 & $25.250,00$ & 49,70 & \\
\hline & 3 & 15,88 & 0,55 & $23.750,00$ & 46,10 & \\
\hline & 4 & 15,88 & 0,57 & $25.062,67$ & 48,88 & \\
\hline & 5 & 15,88 & 0,56 & $23.250,00$ & 45,20 & \\
\hline \multirow{5}{*}{ CC } & 1 & 19,05 & 0,59 & $38.400,00$ & 49,65 & \multirow{5}{*}{44,32} \\
\hline & 2 & 19,05 & 0,56 & $37.326,71$ & 47,91 & \\
\hline & 3 & 19,05 & 0,48 & $30.200,00$ & 39,44 & \\
\hline & 4 & 19,05 & 0,57 & $33.583,47$ & 44,74 & \\
\hline & 5 & 19,05 & 0,48 & $30.750,00$ & 39,86 & \\
\hline
\end{tabular}

Berdasarkan Tabel 6 hasil rata-rata yang didapatkan dari pengujian eksperimental kuat tumpu baut menggunakan metode setengah lubang pada sampel AA sebesar 52,61 MPa; sampel BB sebesar 47,52 MPa; dan sampel CC sebesar 44,32 MPa.

Tabel 7. Hasil Analisis Teoritis Kuat Tumpu Baut Sejajar Serat menggunakan Metode Setengah Lubang

\begin{tabular}{|c|c|c|c|c|}
\hline Sampel & $\begin{array}{c}\text { No. } \\
\text { Sample }\end{array}$ & $\begin{array}{c}\varnothing \text { baut } \\
{[\mathrm{mm}]}\end{array}$ & $\begin{array}{c}F_{e}=70 G \\
{[\mathrm{MPa}]}\end{array}$ & $\begin{array}{c}F_{\text {e rata-rata }} \\
{[\mathrm{MPa}]}\end{array}$ \\
\hline \multirow{5}{*}{$\mathbf{A A}$} & 1 & 12,7 & 41,08 & \multirow{5}{*}{41,60} \\
\hline & 2 & 12,7 & 42,31 & \\
\hline & 3 & 12,7 & 43,63 & \\
\hline & 4 & 12,7 & 41,59 & \\
\hline & 5 & 12,7 & 39,37 & \\
\hline \multirow{5}{*}{ BB } & 1 & 15,875 & 39,06 & \multirow{5}{*}{39,47} \\
\hline & 2 & 15,875 & 40,42 & \\
\hline & 3 & 15,875 & 38,67 & \\
\hline & 4 & 15,875 & 39,75 & \\
\hline & 5 & 15,875 & 39,43 & \\
\hline \multirow{5}{*}{ CC } & 1 & 19,05 & 41,36 & \multirow{5}{*}{37,53} \\
\hline & 2 & 19,05 & 39,11 & \\
\hline & 3 & 19,05 & 33,28 & \\
\hline & 4 & 19,05 & 40,13 & \\
\hline & 5 & 19,05 & 33,75 & \\
\hline
\end{tabular}

Berdasarkan Tabel $\mathbf{7}$ hasil rata-rata yang didapatkan dari Persamaan $\mathbf{2}$ untuk analisis teoritis pada sampel AA sebesar 41,60 MPa; sampel BB sebesar 39,47 MPa; dan sampel CC sebesar $37,53 \mathrm{MPa}$. 
Tabel 8. Perbandingan Hasil Uji Eksperimental Metode Setengah Lubang dengan Analisis Teoritis (SNI 7973:2013)

\begin{tabular}{ccccc} 
Sample & $\begin{array}{c}\emptyset \text { baut } \\
{[\mathbf{m m}]}\end{array}$ & $\begin{array}{c}\boldsymbol{F}_{\text {erata-rata }} \\
\text { Eksperimen } \\
{[\text { MPa] }}\end{array}$ & $\begin{array}{c}\boldsymbol{F}_{\text {erata-rata }} \\
\text { Analisis } \\
{[\text { MPa] }}\end{array}$ & $\begin{array}{c}\text { Persen Beda } \\
{[\%]}\end{array}$ \\
\hline AA & 12,7 & 52,61 & 41,60 & 20,93 \\
\hline BB & 15,875 & 47,52 & 39,47 & 16,95 \\
\hline CC & 19,05 & 44,32 & 37,53 & 15,33 \\
\hline
\end{tabular}

Hasil pengujian eksperimental kuat tumpu baut dengan metode lubang penuh menghasilkan nilai rata-rata lebih besar dari analisis teoritis seperti pada Tabel 8. Perbandingan dari persentase beda antara kuat tumpu eksperimental metode setengah lubang dengan analisis teoritis menunjukkan bahwa pada sampel AA sebesar 20,93\%, sampel BB sebesar 16,95\%, dan pada sampel CC sebesar 15,33\%.

\subsection{Analisis Korelasi Metode Eksperimental Lubang Penuh dan Metode Eksperimental Setengah Lubang Terhadap Metode Analisis Teoritis}

Korelasi merupakan salah satu bentuk analisis dalam statistik yang digunakan untuk mencari hubungan antara dua variabel yang bersifat kuantitatif. Pada pengujian ini yang menjadi variabel $X_{1}$ yaitu metode eksperimental lubang penuh, variabel $X_{2}$ yaitu metode eksperimental setengah lubang, dan variabel $Y$ yaitu persamaan analisis teoritis (SNI 7973:2013). Berikut merupakan data hasil rata-rata kuat tumpu baut yang dihasilkan:

\section{Tabel 9. Berat Jenis Rata-rata dan Kuat Tumpu Rata-rata}

\begin{tabular}{cccc}
\hline Sampel & $\begin{array}{c}\text { Berat Jenis } \\
\text { Rata-rata } \\
{\left[\mathbf{g r} / \mathbf{c m}^{\mathbf{3}} \text { ] }\right.}\end{array}$ & $\begin{array}{c}\text { Kuat Tumpu Rata-rata } \\
\text { Esperimen } \\
{[\mathbf{M P a}]}\end{array}$ & $\begin{array}{c}\text { Analisis Teori } \\
\text { [MPa] }\end{array}$ \\
\hline a & 0,594 & 52,609 & 41,599 \\
\hline b & 0,564 & 47,524 & 39,467 \\
\hline C & 0,536 & 44,318 & 37,526 \\
\hline AA & 0,608 & 55,220 & 42,567 \\
\hline BB & 0,615 & 45,676 & 43,024 \\
\hline CC & 0,632 & 45,989 & 44,260 \\
\hline
\end{tabular}

Berdasarkan Tabel 9 menunjukkan bahwa untuk sampel a memiliki nilai berat jenis rata-rata $0,594 \mathrm{gr} / \mathrm{cm}^{3}$ dengan kuat tumpu rata-rata eksperimental sebesar 52,609 MPa dan kuat tumpu rata-rata analisis teoritis sebesar 41,599 MPa. Pada sampel b memiliki nilai berat jenis ratarata 0,564 gr/ $\mathrm{cm}^{3}$ dengan kuat tumpu rata-rata eksperimental sebesar 47,524 MPa dan kuat tumpu rata-rata analisis teoritis sebesar 39,467 MPa. Pada sampel c memiliki nilai berat jenis rata-rata 0,536 gr/ $\mathrm{cm}^{3}$ dengan kuat tumpu rata-rata eksperimental sebesar 44,318 MPa dan kuat tumpu rata-rata analisis teoritis sebesar 37,526 MPa. Pada sampel AA memiliki nilai berat jenis rata-rata 0,608 gr/ $\mathrm{cm}^{3}$ dengan kuat tumpu rata-rata eksperimental sebesar 55,220 MPa dan kuat tumpu rata-rata analisis teoritis sebesar 42,567 MPa. Pada sampel BB memiliki nilai berat jenis rata-rata $0,615 \mathrm{gr} / \mathrm{cm}^{3}$ dengan kuat tumpu rata-rata eksperimental sebesar 45,676 MPa dan kuat tumpu rata-rata analisis teoritis sebesar 43,024 MPa. Dan pada sampel CC memiliki nilai berat jenis rata-rata $0,632 \mathrm{gr} / \mathrm{cm}^{3}$ dengan kuat tumpu rata-rata eksperimental sebesar 45,989 MPa dan kuat tumpu rata-rata analisis teoritis sebesar 44,260 MPa. 


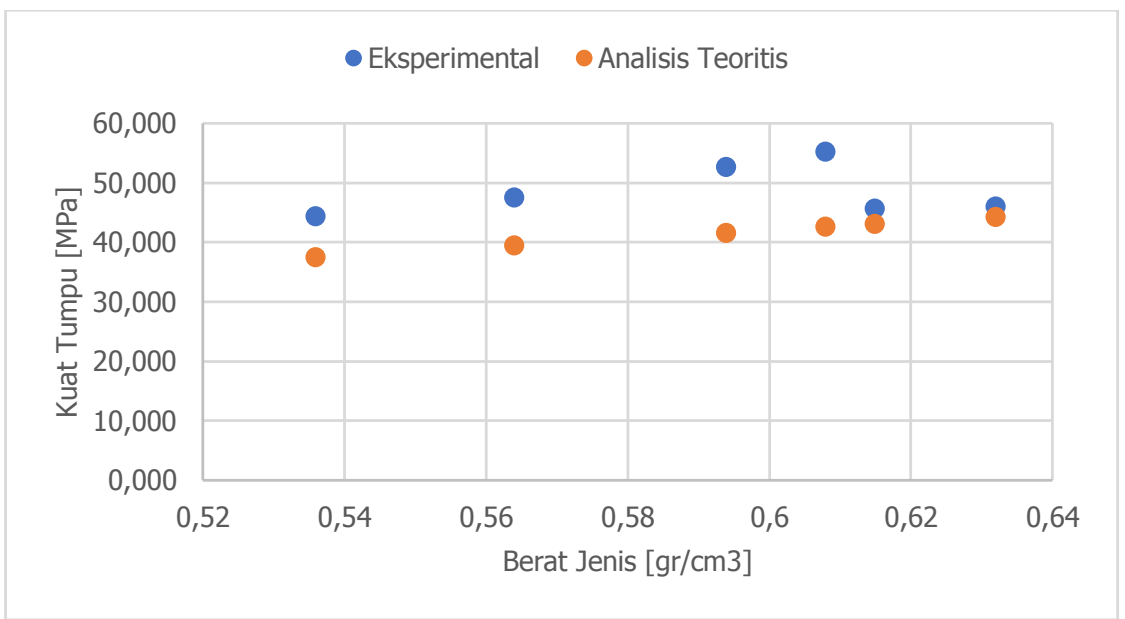

Gambar 5. Hubungan berat jenis rata-rata terhadap kuat tumpu rata-rata

Korelasi menunjukkan untuk hasil pengujian eksperimental menghasilkan nilai yang lebih besar dari analisis teoritis (SNI 7973:2013) seperti yang ditunjukkan pada Gambar 5.

\section{KESIMPULAN DAN SARAN}

\subsection{Kesimpulan}

Setelah dilakukan analisis dari hasil pengujian kuat tumpu sejajar serat kayu Mahoni, didapatkan beberapa kesimpulan sebagai berikut:

1. Hasil menunjukan perbandingan dari uji eksperimental kuat tumpu baut rata-rata dengan analisis teoritis (SNI 7973:2013), untuk pengujian metode lubang penuh pada sampel a sebesar 55,22 MPa dengan persen beda 22,91\%; sampel b sebesar 45,68 MPa dengan persen beda 5,81\%; sampel c sebesar 45,99 MPa dengan persen beda 3,76\%; untuk pengujian metode setengah lubang pada sampel AA sebesar 52,61 MPa dengan persen beda 20,93\%; sampel BB sebesar 47,52 MPa dengan persen beda 16,95\%; dan sampel CC sebesar 44,32 MPa dengan persen beda 15,33\%.

2. Korelasi menunjukkan bahwa pengujian eksperimental menghasilkan nilai yang lebih besar dari analisis teoritis.

\subsection{Saran}

Dilakukan penelitian lebih lanjut dengan menggunakan jenis kayu yang berbeda dan arah serat yang berbeda.

\section{DAFTAR RUJUKAN}

ASTM D5764-97a. (2002). Standard Test Method for Evaluating Dowel-Bearing Strength of Wood and Wood Based Product. West Conchohocken: ASTM International.

Badan Standardisasi Nasional. (2013). SNI 7973:2013 tentang Spesifikasi Desain Untuk Konstruksi Kayu. Jakarta: Badan Standardisasi Nasional.

Smith, I., Whale, L. R. J., Anderson, C., Hilson, B. O. \& Rodd, P. D. (1988). Design Properties of Laterally Loaded Nailed or Bolted Wood Joints. Journal Civil Engineering, 15, 633643.

Wilkinson, T. (1991). Dowel Bearing Strength. Madison, Winconsin: Forest Product Laboratory, United States Department of Agriculture. 